\title{
ETIOLOGICAL AGENTS OF DIARRHEA IN PATIENTS INFECTED BY THE HUMAN IMMUNODEFICIENCY VIRUS-1: A REVIEW
}

Andréa Regina Baptista ROSSIT(1,4), Ana Carolina Musa GONÇALVES(1,2), Célia FRANCO(3) \& Ricardo Luiz Dantas MACHADO(1,4)

\begin{abstract}
SUMMARY
Despite the importance of understanding the epidemiology of agents responsible for infectious diarrhea in human immunodeficiency virus (HIV)/acquired immunodeficiency syndrome (AIDS) population, the number of articles about this subject is relatively few. The current article summarizes published data on bacterial, fungal, viral and parasitic enteropathogens in the HIV/AIDS seropositive subjects in different countries, regions and localities. In general, there is a great difference in the frequencies of etiological agents due to factors which include immune status, geographical location, climate and socioeconomic conditions. It is important to stress that a great prevalence of infection by emergent agents has been reported in the more advanced stages of AIDS. Therefore, to establish specific treatment depends directly on knowledge of these agents and risk factors associated to their distribution. Moreover, the colonization by potential pathogenic agents verified in these individuals is high thus implicating that they act as carriers. Finally, public health measures of control and prevention must take into consideration the regional previously identified enteropathogens, especially in areas where HIV prevalence is high.
\end{abstract}

KEYWORDS: Enteropathogens; Prevalence; Diarrhea; HIV; AIDS.

In spite of worldwide efforts and the promising advances aimed at the control of acquired immunodeficiency syndrome (AIDS), whether for prevention or treatment, the number of individuals infected by the human immunodeficiency virus (HIV) is growing as is the number of deaths related to this disease. In fact in 2006, 4.3 million adults and children were identified as newly infected throughout the world ${ }^{90}$. In Latin America, one third of HIV seropositive individuals are concentrated in Brazil, a country that mirrors this worldwide increase ${ }^{10,91}$.

Superimposed infections due to defective immunity are a major health problem among HIV seropositive patients. Intestinal pathogen infection, which is also one of the basic health problems in tropical regions, is common in these patients ${ }^{55}$. Among the possible clinical manifestations of AIDS, diarrhea represents a great concern ${ }^{20}$ as this group is susceptible to both classic pathogens and different opportunistic agents ${ }^{16-18,61,65}$ malnutrition and, ultimately, death may be associated to these co-infections ${ }^{92}$. Furthermore, aggravating this condition, antibacterial chemoprophylaxis, commonly prescribed to this group of patients, causes severe damage to gastrointestinal flora ${ }^{72}$. Therefore, diarrhea is being considered a significant cause of morbidity and mortality among HIV/AIDS patients. Indeed, this is the second most common diagnosis and, in developing countries, affects approximately $90 \%$ of patients with AIDS $4,26,55,69$.

In addition, diarrhea in patients with HIV infection is a big challenge because, apart from etiologies common to the general population, one must consider non-infectious clinical manifestations due to the wellknown adverse reaction to antiretroviral drugs ${ }^{11,44,80,95}$. However, noninfectious diarrhea, for the majority of patients, is limited to a period of one to two months ${ }^{70}$. On the other hand, there are those who require greater medical attention since low TCD $4^{+}$cell counts $\left(\leq 200\right.$ cells $\left./ \mathrm{mm}^{3}\right)$ cause greater susceptibility to the infectious form ${ }^{22,95}$.

Due to the importance of knowledge on microorganisms implicated in infectious diarrhea and on the individual and collective impact of infection, there is a need for more publications on this subject ${ }^{93}$. This fact becomes more evident when it comes to the HIV/AIDS group, in which the majority of publications are on the enteroparasites infections ${ }^{96}$. This article aims to summarize published data on bacterial, fungal, viral and parasitic enteropathogens in HIV/AIDS populations from different countries, regions and localities since the broad socioeconomic, climatic and geographic diversity is known to impact their significance ${ }^{18,78}$.

\section{Bacteria}

Although the isolation of Enterobacteriaceae from the gastrointestinal tract of immunocompromised individuals has been interpreted as colonization due to the absence of clinical signs, characterizing an asymptomatic carrier, infectious diarrhea by this group of microorganisms does frequently occur. Bacteria usually isolated in the population are

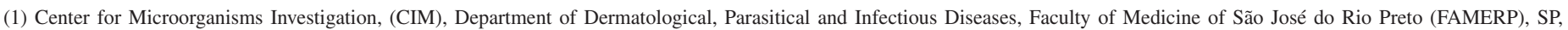
Brazil.

(2) Universitary Center of Rio Preto (UNIRP), São José do Rio Preto, SP, Brazil.

(3) Infectious and Parasitical Diseases Service, Hospital de Base (DIP-HB), Regional Faculty of Medicine, São José do Rio Preto Foundation (FUNFARME), SP, Brazil.

(4) Regional Faculty of Medicine, São José do Rio Preto Foundation, São José do Rio Preto, São Paulo, Brazil.

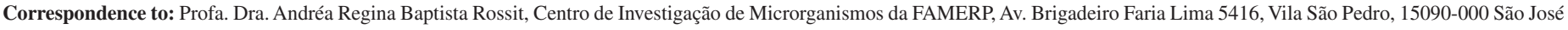
do Rio Preto, São Paulo, Brasil. Phone/FAX: +55.17.3201-5909. E-mail: andrea@ famerp.br 


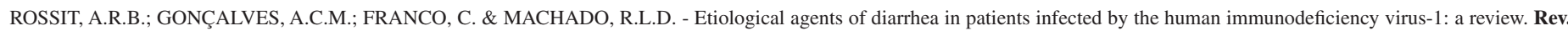
Inst. Med. trop. S. Paulo, 51(2): 59-65, 2009.

the same detected in the group of immunocompetent: Escherichia coli, Salmonella sp. and Shigella sp. ${ }^{71,95}$. Nevertheless, traditional diagnostic methods are in general limited on the isolation and identification of opportunistic or emerging bacteria ${ }^{93}$.

Several strains of the $E$. coli species described as important pathogens (E. coli enterotoxigenic-ETEC, E. coli enteroaggregative-EAEC, E. coli diffusely adherent-DAEC, E. coli enteroinvasive-EIEC, and E. coli Enterohemorragic-EHEC) are responsible for about $25 \%$ of acute diarrhea in immunocompetent individuals ${ }^{71}$. In HIV seropositive patients, this species has been strongly associated with persistent diarrhea with a great diversity of virulence factors and consequent effects. In Africa, GASSAMA-SOW et al. ${ }^{37}$ found a positive correlation between chronic diarrhea and the isolation of $E$. coli from the intestinal mucosa of AIDS patients. However, in Brazil this association was not seen in a HIVinfected infant population in which similar frequencies of colonizing $E$. coli were found in diarrheic and non-diarrheic children ${ }^{78}$. Other authors associated EAEC with diarrhea severity (intestinal inflammation and blood in stools) and a higher isolation frequency (70\%) among AIDS patients in comparison to the HIV seronegative population ${ }^{85,94}$.

There seems to be no differences related to the immune condition and the commonest isolated species of the Shigella genus ${ }^{6}$, although an approximately twenty-fold increase in risk to develop gastroenteritis has been described in AIDS patients carrying this bacterium compared to the general population ${ }^{35,36}$. Recently, S. sonnei was detected in $11 \%$ of diarrheic HIV-infected children from the Northwestern region of São Paulo State, Brazil ${ }^{78}$, but without a positive association with this condition. Approximately the same percentage of Shigella sp. was reported for adult HIV seropositive diarrheic individuals from Southern India ${ }^{54}$. Salmonella sp. can be considered another important pathogen for the HIV-infected group as these enterobacteria are 20 to 100 times more frequently isolated among HIV individuals compared to the immunocompetent population ${ }^{13,60}$. The frequencies of Salmonella isolation varies from $2.5 \%$ to $18 \%$ with the highest percentages in African children ${ }^{2,54}$. A special mention must be made to non-typhoid salmonella because of its severe, invasive and recurrent pattern in HIV-infected individuals ${ }^{2,19,52}$. Enteric salmonellosis was also more frequently seen in patients in the advanced stages of HIV infection and with impaired nutritional status ${ }^{86}$.

Among enteric bacterial pathogens, Campylobacter jejuni has been detected in significantly higher frequencies among HIV positive populations ${ }^{54}$. In countries of South Asia and on the African continent, C. jejuni detection varied between $3.8 \%$ and $13.1 \%$, respectively, in diarrheic feces from HIV seropositive individuals ${ }^{5,54,73}$. On performing specific investigations of non-jejuni species, it was found that other members of the Campylobacter sp. genus are frequently detected in the stools of HIV-infected patients ${ }^{83}$ and also that these may be associated with prolonged mild to moderate diarrhea in HIV-infected patients ${ }^{49}$. Another aggravating fact is that patients under continuous antibiotic therapy, a situation common among HIV-infected individuals, have greater tendency to carry resistant strains of all the bacterial genera mentioned above, to the main treatment and/or chemoprophylactic drugs such as trimethoprim-sulfamethoxazole, nalidixic acid, erythromycin, ampicillin and quinolones ${ }^{13,54,57,83}$. The Mycobacterium sp. species, especially from the $M$. avium complex (MAC), were also detected in the feces of HIV-infected patients at frequencies of around $15 \%$ but without significant association with diarrhea ${ }^{46,56,62,68}$. However, case reports show the unequivocal involvement of non-tuberculous mycobacteria, such as M. ulcerans, in chronic diarrhea ${ }^{47}$ and $M$. avium intracellular-caused duodenitis in these patients ${ }^{79}$.

\section{Virus}

Viral enteritis is a well known manifestation among HIV seropositive patients, but the involvement of its etiological agents seems to vary greatly depending on the origin and age of the population assessed. In general, the percentage of detection of at least one enteric virus ranged from 6.4 to $52 \%$ in Venezuelan HIV-infected individuals ${ }^{42,59}$ and from 20 to $35 \%$ in HIV seropositive populations from Argentina and the United States of America ${ }^{39,43}$. Rotavirus is one of the main causes of infantile gastroenteritis due to the greater exposure of children ${ }^{87}$. Among the HIV seropositive infantile population, the data are divergent depending on the geographical region considered with frequencies of isolation of $0 \%, 5 \%$ and $30 \%$ in Brazilian $^{78}$, Venezuelan ${ }^{59}$ and Malaysian ${ }^{21}$ children, respectively. Also, in studies of adult HIV seropositive populations, rotavirus was detected in $18 \%$ of the patients in a study in England ${ }^{89}$, $13.6 \%$ in Germany ${ }^{1}, 8.2 \%$ in Senegal ${ }^{35}$ and in $2.5 \%$ of samples collected in the Northern region of Brazil ${ }^{33}$ and so demonstrated considerable regional and/or seasonal variability.

Astroviruses are members of the Astroviridae family and are recognized as a common cause of gastroenteritis not only in infants but also among elderly and immunocompromised patients ${ }^{63}$. The main symptom of infection by astroviruses is a watery diarrhea that may be associated with fever, vomiting, anorexia and abdominal pain ${ }^{32}$. In Venezuela and Argentina, the virus was undetected ${ }^{42}$ or detected at frequencies of $4 \%$ in people with HIV, respectively, without, however, being significantly associated with diarrhea. The same was observed in the Southeast of Brazil among seropositive non-diarrheic children, but with a higher frequency of isolation $(11 \%)^{78}$. Viruses such as picobirnavirus and calicivirus have frequently been described in diarrheic and nondiarrheic fecal samples of individuals with HIV. Picobirnaviruses have been identified in the feces of several species of vertebrates, including humans, but their associations with diarrhea in animals or among HIV seronegative individuals are not clear. Nevertheless, among HIV positive patients, infection by picobirnavirus has been significantly associated with diarrhea $a^{38,39,43}$, with reports that such patients have problems on clearing this infection ${ }^{43}$. Caliciviruses are considered the principal cause of viral outbreak in the world and more recently as one of the main causes of acute gastroenteritis among children. A wide variation in positivity (6\% to $51 \%$ ) was demonstrated involving both HIV seropositive adults and children ${ }^{30,42,77,89}$ which indicates that future studies should attempt to elucidate their participation as etiological agents of diarrhea in these populations. Recent data on an adult HIV seropositive population from Northeastern São Paulo State showed a significant association between calicivirus detection and diarrhea in a case-control study ${ }^{40}$.

\section{Yeast}

Despite of bacteria, parasites and viruses being the most important enteropathogens that cause infectious diarrhea, the importance of Candida sp. as a colonizer of the gastrointestinal mucosa of HIV-positive patients is unquestionable, mainly in respect to the group denominated as "non-albicans". The isolation of $C$. albicans in stools of patients from differing countries such as Senegal ${ }^{35,36}$, Cameroon ${ }^{81}$, India ${ }^{3}$ and Ivory Coast ${ }^{88}$ has shown a variation of $7.6 \%$ to $39.1 \%$. In Brazil, the results of 


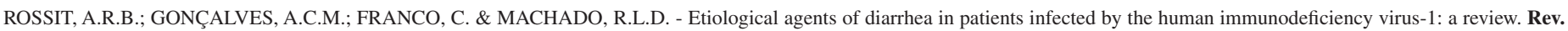
Inst. Med. trop. S. Paulo, 51(2): 59-65, 2009.

ROSSIT et al. ${ }^{78}$ were comparable with the highest published frequencies $(35 \%)$ reported in HIV seropositive children. Indeed, these pathogens have been reported as opportunistic in the gastrointestinal tract and are considered in some situations the only etiological agent necessary for diarrheic symptoms ${ }^{15,27}$ or relevant only when associated with other microorganisms $s^{14,31,53}$. Anyway, their importance is based on the growing incidence of isolation in oral and esophageal mucous membranes and even in the blood stream (candidemia) and their intrinsic or acquired resistance to the main available antifungal drugs ${ }^{78}$. This raises the need for additional systematic investigation on the participation of this genus on infectious diarrhea etiology among the HIV positive group.

\section{Parasites}

Infections caused by intestinal parasites have been studied much more than any other infection in HIV seropositive individuals and AIDS patients. These infections receive special attention as the cause of diarrhea. In the context of the commonest identified parasites are Giardia lamblia, Entamoeba histolytica, Strongyloides stercoralis, Ascaris lumbricoides and Ancylostoma duodenale ${ }^{12,26,48,74}$. Apart from the classical protozoa, emergent species such as Cryptosporidium parvum, Microsporidia, Cyclospora cayetanensis and Isospora belli have also been frequently mentioned in the literature $\mathrm{e}^{9,14,26,74}$.

A study in India identified different pathogens related to diarrhea in HIV-1 infected patients. C. parvum presented with the highest frequency (33\%) but G. lamblia (13.3\%), Microsporidium (6.7\%) and I. belli $(2.7 \%)$ were also detected. The authors also observed that the cases of chronic diarrhea were statistically associated to polyparasitism and with lower $\mathrm{TCD}^{+}{ }^{+}$cell counts ${ }^{26}$. In another region of the country, an investigation of the HIV seropositive adult population with acute or chronic diarrhea identified E. histolytica (14.9\%) as the most prevalent enteroparasite followed by Cryptosporidium (8.5\%), S. stercoralis (5.3\%) and G. lamblia $(4.3 \%)^{50}$. On the other hand, DEODHAR et al. ${ }^{25}$ identified Cyclospora in $6.6 \%$ of patients with AIDS in an Indian hospital and found that half of these had infections which were mainly associated with Cryptosporidium. Investigations of adult African patients infected by HIV demonstrated a varied panorama of enteroparasites, both in diarrheic patients and in non-diarrheic individuals. In non-diarrheic patients, A. lumbricoides was the most common helminth identified (30.8\%) followed by S. stercoralis $(5.1 \%)$. In respect to the protozoa in this group, E. histolytica $(10.3 \%)$ and G. lamblia $(3.8 \%)$ were the commonest ${ }^{45}$. In patients with diarrhea, Cryptosporidium, Microsporidium and E. histolytica were the most prevalent intestinal protozoa ${ }^{35,64}$.

In Europe, an investigation of patients with HIV in South Italy also demonstrated a significant association between intestinal symptoms and TCD4 ${ }^{+}$lymphocyte counts below 200 cells $/ \mathrm{mm}^{3}$. In this work, among the 65 patients with diarrhea, the following protozoa were identified: $C$. parvum $(21.5 \%)$, Blastocystis hominis $(10.7 \%)$, Microsporidium $(9.2 \%)$, G. lamblia $(6.1 \%)$ and I. belli $(1.5 \%)^{7}$. In Americas, two researches conducted in adult patients infected by HIV-1 in Peru, demonstrated that Cryptosporidium was the main protozoan associated with diarrhea ${ }^{13,34}$. Additionally, in Cuba, C. parvum was found in $13.1 \%$ of all HIV seropositive patients and a positive association was verified with less than $200 \mathrm{TCD}^{+}{ }^{+}$cell count ${ }^{23}$. Apart from this enteroparasite, G. lamblia, S. stercoralis and I. belli were also evidenced but without this association. Interestingly, KAMINSKY et al. ${ }^{51}$ studied HIV seropositive individuals in Honduras and did not identify any cases of giardiasis, amebiasis and cryptosporidiosis. The authors demonstrated a strong association between eosinophilia and the presence of intestinal helminthosis caused by Trichuris trichiura (11\%), A. lumbricoides $(12 \%)$ and S. stercoralis $(13.2 \%)$. On the other hand, other authors in the same country detected C. parvum (7.7\%), S. stercoralis (7.7\%), C. cayetanensis (1.9\%) and B. hominis $(1.9 \%)$ exclusively in persons infected with HIV ${ }^{58}$, and, also, no association with diarrhea was observed. In Haiti, the infection by $I$. belli $(15.0 \%)$ was associated with chronic diarrhea and weight loss in patients with AIDS $^{24}$. Furthermore, in United States, three earlier reports associated $C$. parvum as an important pathogen in HIV patients, and its frequency ranged from $3.8 \%$ to $10.0 \%{ }^{28,66,84}$. Moreover, the prevalence of other enteric parasites among these HIV-infected attendees of the AIDS clinic was: G. lamblia (55\%), I. belli (10\%) and E. histolytica $(3 \%)^{28}$.

In Brazil, some studies have evaluated the frequency of enteroparasites in the HIV population as well as their association with TCD4+ cell counts, viral load and the presence of diarrhea. In fecal samples collected from in-patients in a hospital in Ceará State, Northeastern region of Brazil, where $49 \%$ had AIDS, a significant association was found between the presence of $C$. parvum and Microsporidium ${ }^{97}$. In contrast, in the same Brazilian region, in an AIDS patients' service of a university hospital in Bahia State, no association was observed for the TCD4+ lymphocyte count, the viral load and the presence of intestinal parasites. However, the presence of S. stercoralis and G. lamblia was greater among individuals infected by the HIV ${ }^{29}$.

In Southeastern Brazil, where the highest number of cases $(67.8 \%)$ of individuals infected by HIV and with AIDS in the country is found ${ }^{10}$, the panorama of infections and associations with the clinical characteristics of individuals infected by HIV also showed variability similar to that described above ${ }^{78}$. In the State of Rio de Janeiro, two published studies did not report any positive association between the presence of enteroparasites and diarrhea ${ }^{67,75}$. However, Cryptosporidium was the commonest protozoan. Additionally, MOURA et al. ${ }^{67}$ detected the presence of other parasites in the feces of HIV/AIDS patients attended in a university hospital, including S. stercoralis and G. lamblia (15.2\%), E. histolytica (13.1\%), A. lumbricoides (11.1\%) and I. belli (10.1\%). In Uberlândia, State of Minas Gerais, the occurrence of infections by intestinal parasites in AIDS patients was $12 \%$, infected by $S$. stercoralis, $7 \%$ by $I$. belli, $4 \%$ by Cryptosporidium sp. and $4 \%$ by helminth infections. Of these patients, those classified as chronic alcoholics were more commonly infected by S. stercoralis $(64.3 \%)^{82}$. In another research in Uberaba, also in the State of Minas Gerais, patients with diarrhea and TCD $4^{+}$counts of less than 200 cells $/ \mathrm{mm}^{3}$ presented with high frequencies of I. belli (10.3\%) and Cryptosporidium (8.6\%), thereby demonstrating the opportunistic profile of these infections and their relationship with the immunological state of the individual ${ }^{22}$. The authors also reported the impossibility of an association with highly active antiretroviral therapy (HAART), as only $8.5 \%$ of HIV patients positive for these coccidia received this therapy regularly, and they observed that the seasonal factor was important for justifying the presence of Cryptosporidium. An investigation of HIV patients in the city of São Paulo found a prevalence of $14.3 \%$ for Cryptosporidium sp. in patients with AIDS and with diarrhea, which was statistically significant for patients with low TCD4 ${ }^{+}$counts $^{76}$. Subsequently, another investigation in the same city, demonstrated a significant association between diarrhea and the presence of cryptosporidiosis, giardiasis and isosporidiasis. However, no association was identified between TCD4 ${ }^{+}$counts and the detection of any specific parasite ${ }^{18}$. In the Northwestern region of São 
ROSSIT, A.R.B.; GONÇALVES, A.C.M.; FRANCO, C. \& MACHADO, R.L.D. - Etiological agents of diarrhea in patients infected by the human immunodeficiency virus-1: a review. Rev. Inst. Med. trop. S. Paulo, 51(2): 59-65, 2009.

Paulo State, three studies have been carried out on this theme; two in the adult population ${ }^{14,41}$ and the other in infants ${ }^{78}$. In the studies of 2004 and 2007 no association was found between the presence of intestinal parasites and diarrhea. However, in the infant population the consumption of raw foods and severe imunossupression were associated with this symptom. In these two studies the frequencies of Cryptosporidium were $9.09 \%$ and $62 \%$, of G. lamblia were $4.04 \%$ and $9 \%$ and of E. histolytica were $0 \%$ and $1 \%$, respectively. Recently, in the third evaluation on the same Brazilian region, HIV seropositive adults had diarrhea positively associated with G. lamblia in a case control study carried out during the years of 2006 and $2007^{41}$. This point to the need for a continuous surveillance of enteroparasites in this population.

\section{Concluding remarks}

It is important to emphasize that the greatest prevalence of emergent agents is seen, without doubt, in the more advanced stages of AIDS, a phenomenon that is observed after the start of antiretroviral therapy and which greatly affects survival $5,6,8,38,42$. Thus, infection by HIV may be accompanied by severe cases of diarrhea thereby instigating important studies on opportunistic and saprophyte pathogens ${ }^{18}$. Still further elucidation is necessary in order to identify any association between diarrhea, so common in sufferers with this virus and the low TCD4 ${ }^{+}$cell counts. Hence, the criteria utilized to establish specific treatment should be analyzed including the severity of diarrhea which depends on the immunological state of the patient and of the virulence of the pathogen involved $^{8,9}$. These studies are important tools for interventions in patients with HIV/AIDS, enabling a better understanding of the etiology of diarrhea ${ }^{13}$, as well as favoring the quality of life of these patients.

Moreover, the colonization by potential pathogenic agents verified in asymptomatic HIV-seropositive individuals is high which may result from immunologic tolerance, virulence variations, or drawn-out liberation of microorganisms after the last episode of diarrhea ${ }^{11}$. This review emphasizes that although some of these studies showed no association between diarrhea and a specific enteropathogen, the HIV/AIDS population still harbor these organisms and act as carriers. Therefore, their potential role in dissemination must be further evaluated. Important questions for diarrhea controlling in the HIV seropositive population, such as the identification of other opportunistic agents, beyond subgroups, variants, and pertinent factors of virulence, remains to be answered ${ }^{78}$. To accomplish this goal, improving traditional diagnostic and/or creating new laboratory methods is crucial.

The differences on the importance of each agent may be due to local geographical differences and/or the fact that different studies evaluated distinct groups of enteric pathogens. Finally, public health measures of control and prevention must take into consideration the regional previously identified enteropathogens, especially in areas where HIV prevalence is high.

\section{RESUMO}

\section{Agentes etiológicos da diarréia em pacientes infectados pelo vírus da imunodeficiência tipo-1: revisão}

Muito embora a importância do conhecimento sobre a epidemiologia dos agentes responsáveis pela diarréia infecciosa nos portadores do vírus da imunodeficiência humana (HIV) e/ou doentes pela síndrome da imunodeficiência adquirida (SIDA), o número de artigos científicos sobre o tema é relativamente pequeno. Este artigo resume os dados já publicados sobre os enteropatógenos bacterianos, fúngicos, virais e parasitários que acometem os indivíduos soropositivos para o HIV e/ou doentes pela SIDA em diferentes países, regiões e localidades. Em geral, existe uma grande diferença nas frequiências dos agentes etiológicos, devido a fatores que incluem status imunológico, localização geográfica, clima e condições socioeconômicas. Ressalta-se, que é grande a prevalência de infecção por agentes emergentes nos estágios mais avançados da SIDA. Portanto, o estabelecimento de tratamento específico depende diretamente do conhecimento desses agentes bem como dos fatores de risco associados à sua distribuição. Ademais, a colonização por patógenos em potencial nesses indivíduos é elevada o que determina o estado de portadores assintomáticos. Por fim, medidas em saúde pública relativas ao controle e prevenção da diarréia nessa população devem considerar os enteropatógenos de importância regional, especialmente em áreas onde a prevalência do HIV é elevada.

\section{ACKNOWLEDGEMENTS}

To David Andrew Hewitt for the English revision of this manuscript.

\section{REFERENCES}

1. ALBRECHT, H.; STELLBRINK, H.J.; FENSKE S. et al. - Rotavirus antigen detection in patients with HIV infection and diarrhea. Scand. J. Gastroent., 28: 307-310, 1993.

2. AMADI, B.; KELLY, P.; MWIYA, M. et al. - Intestinal and systemic infection, HIV, and mortality in Zambian children with persistent diarrhea and malnutrition. J. pediat. Gastroent. Nutr., 32: 550-554, 2001.

3. ANAND, L.; DHANACHAND, C. \& BRAJACHAND, N. - Prevalence and epidemiologic characteristics of opportunistic and non-opportunistic intestinal parasitic infections in HIV positive patients in Manipur. J. commun. Dis., 30: 19-22, 1998.

4. ATTILI, S.V.; GULATI, A.K.; SINGH, V.P. et al. - Diarrhea, CD4 counts and enteric infections in a hospital - based cohort of HIV-infected patients around Varanasi, India. BMC infect. Dis., 6: 39, 2006.

5. AWOLE, M.; GEBRE-SELASSIE, S.; KASSA, T. \& KIBRU, G. - Isolation of potential bacterial pathogens from the stool of HIV-infected and HIV-non-infected patients and their antimicrobial susceptibility patterns in Jimma Hospital, South west Ethiopia. Ethiop. med. J., 40: 353-364, 2002.

6. BAER, J.T.; VUGIA, D.J.; REINGOLD, A.L. et al. - HIV infection as a risk factor for Shigellosis. Emerg. infect. Dis., 5: 820-823, 1999.

7. BRANDONISIO, O.; MAGGI, P.; PANARO, M.A. et al. - Intestinal protozoa in HIVinfected patients in Apulia, South Italy. Epidemiol. Infect., 123: 457-462, 1999.

8. BRANTLEY, R.K.; WILLIAMS, K.R.; SILVA, T.M. et al. - AIDS-associated diarrhea and wasting in Northeast Brazil is associated with subtherapeutic plasma levels of antiretroviral medications and with both bovine and human subtypes of Cryptosporidium parvum. Braz. J. infect. Dis., 7: 16-22, 2003.

9. BRASIL, P.; DE LIMA, D.B.; DE PAIVA, D.D. et al. - Clinical and diagnostic aspects of intestinal microsporidiosis in HIV-infected patients with chronic diarrhea in Rio de Janeiro, Brazil. Rev. Inst. Med. trop. S. Paulo, 42: 299-304, 2000.

10. BRAZIL. MINISTRY OF HEALTH - DST/AIDS. Available in: http://www.AIDS.gov. br. Accessed in 10/19/2008. 
ROSSIT, A.R.B.; GONÇALVES, A.C.M.; FRANCO, C. \& MACHADO, R.L.D. - Etiological agents of diarrhea in patients infected by the human immunodeficiency virus-1: a review. Rev. Inst. Med. trop. S. Paulo, 51(2): 59-65, 2009.

11. BRINK, A-K.; MAHÉ, C.; WATERA, C. et al. - Diarrhea, CD4 counts and enteric infections in a community-based cohort of HIV adults in Uganda. J. Infect., 45: 99-106, 2002

12. BÜYÜKBABA BORAL, O.; UYSAL, H.; ALAN, S. \& NAZLICAN O. - Investigation of intestinal parasites in AIDS patients. Mikrobiyol. Bul., 38: 121-128, 2004.

13. CÁRCAMO, C.; HOOTON, T.; WENER, M.H., et al. - Etiologies and manifestations of persistent diarrhea in adults with HIV-1 infection: a case-control study in Lima, Peru. J. infect. Dis., 191: 11-19, 2005.

14. CARDOSO, L.V.; MARQUES, F.R.; CAVASINI, C.E. et al. - Correlation of intestinal parasitic pathogens in HIV-seropositive adult with and without diarrhea in Northeast region of São Paulo State, Brazil. Rev. panamer. Infectol., 6(2): 8-11, 2004.

15. CHAUDHURY, A.; NATH, G.; SHUKLA, B.; PANDA, S. \& SINGH, T.B. - Diarrhoea associated with Candida spp.: incidence and seasonal variation. J. Diarrhoeal Dis. Res., 14: 110-112, 1996.

16. CIMERMAN, S.; CASTAÑEDA, C.G.; IULIANO, W.A. \& PALACIOS, R. - Perfil das enteroparasitoses diagnosticadas em pacientes com infecção pelo vírus HIV na era da terapia antiretroviral potente em um centro de referência em São Paulo, Brasil. Parasit. latinoamer., 57: 111-119, 2002

17. CIMERMAN, S.; CIMERMAN, B. \& LEWI, D.S. - Avaliação da relação entre parasitoses intestinais e fatores de risco para o HIV em pacientes com AIDS. Rev. Soc. bras. Med. trop., 32: 181-185, 1999.

18. CIMERMAN, S.; CIMERMAN, B. \& LEWI, D.S. - Prevalence of intestinal parasitic infections in patients with acquired immunodeficiency syndrome in Brazil. Int. J. infect. Dis., 3: 203-206, 1999.

19. ClERINX, J.; BOGAERTS, J.; TAELMAN, H. et al. - Chronic diarrhea among adults in Kigali, Rwanda: association with bacterial enteropathogens, rectocolonic inflammation, and human immunodeficiency virus infection. Clin. infect. Dis., 21 1282-1284, 1995.

20. COLEBUNDERS, R.L. \& LATIF, A.S. - Natural history and clinical presentation of HIV-1 infection in adults. AIDS, 5: S103-S112, 1991.

21. CUNLIFFE, N.A.; GONDWE, J.S.; KIRKWOOD, C.D. et al. - Effect of concomitant HIV infection on presentation and outcome of rotavirus gastroenteritis in Malawian children. Lancet, 358: 550-555, 2001.

22. DE OLIVEIRA-SILVA, M.B.; DE OLIVEIRA, L.R.; RESENDE, J.C. et al. - Seasonal profile and level of CD4+ lymphocytes in the occurrence of cryptosporidiosis and cystoisosporidiosis in HIV/AIDS patients in the Triângulo Mineiro region, Brazil. Rev. Soc. bras. Med. trop., 40: 512-515, 2007.

23. DE PAZ, V.C.; BRÍNGUEZ, M.B.; VIAMONTE, B.V. et al. - Diagnóstico de coccidias y microsporas en muestras de heces diarreicas de pacientes cubanos seropositivos al VIH: primer reporte de microsporas en Cuba. Rev. cuba. Med. trop., 55: 14-18, 2003.

24. DEHOVITZ, J.A.; PAPE, J.W.; BONCY, M. \& JOHNSON Jr., W.D. - Clinical manifestations and therapy of Isospora belli infection in patients with the acquired immunodeficiency syndrome. New Engl. J. Med., 315: 87-90, 1986.

25. DEODHAR, L.; MANIAR, J.K. \& SAPLE, D.G. - Cyclospora infection in acquired immunodeficiency syndrome. J. Ass. Phycns India, 48: 404-406, 2000.

26. DWIVEDI, K.K.; PRASAD, G.; SAINI, S. et al. - Enteric opportunistic parasites among HIV infected individuals: associated risk factors and immune status. Jap. J. infect. Dis., 60: 76-81, 2007.

27. ENWEANI, I.B.; OBI, C.L. \& JOKPEYIBO, M. - Prevalence of Candida species in Nigerian children with diarrhoea. J. Diarrhoeal Dis. Res., 12: 133-135, 1994.
28. ESFANDIARI, A.; JORDAN, W.C.; BROWN, C.P. et al. - Prevalence of enteric parasitic infection among HIV-infected attendees of an inner city AIDS clinic. Cell. mol. Biol., 41: 19-23, 1995 .

29. FEITOSA, G.; BANDEIRA, A.C.; SAMPAIO, D.P.; BADARÓ, R. \& BRITES, C. - High prevalence of giardiasis and strongyloidiasis among HIV-infected patients in Bahia, Brazil. Braz. J. infect. Dis., 5: 339-344, 2001

30. FERREIRA, M.S.; XAVIER, M.P.; FUMIAN, T.M. et al. - Acute gastroenteritis cases associated with noroviruses infection in the state of Rio de Janeiro. J. med. Virol. 80: $338-344,2008$.

31. FORBES, D.; EE, L.; CAMER-PESCI, P. \& WARD, P.B. - Faecal candida and diarrhoea Arch. Dis. Childh., 84: 328-331, 2001.

32. GABBAY, Y.B.; LUZ, C.R.; COSTA, I.V. et al. - Prevalence and genetic diversity of astroviruses in children with and without diarrhea in São Luís, Maranhão, Brazil Mem. Inst. Oswaldo Cruz, 100: 709-714, 2005

33. GABBAY, Y.B.; SILVA, L.D. \& GOMES, M.L.C. - Viral enteropathogens in gastroenteritis episodes among HIV infected patients. In: $12^{\text {th }}$ National Meeting of Virology a $4^{\text {th }}$ Mercosul Meeting of Virology, Caldas Novas, Brazil, 2001. Virus Rev. Res., 6(2, suppl. 1), 2001

34. GARCÍA, C.; RODRÍGUEZ, E.; DO, N. et al. - Parasitosis intestinal en paciente con infección VIH-SIDA. Rev. Gastroent. Peru, 26: 21-24, 2006.

35. GASSAMA, A.; SOW, P.S.; FALL, F. et al. - Ordinary and opportunistic enteropathogen associated with diarrhea in Senegalese adults in relation to human immunodeficiency virus serostatus. Int. J. infect. Dis., 5: 192-198, 2001.

36. GASSAMA, A.; THIAW, B.; DIA, N.M. et al. - Etiologies infectieuses des diarrhées de l'adulte au cours de l'infection VIH à Dakar: étude cas/témoins sur 594 malades. Dakar méd., 46: 46-50, 2001.

37. GASSAMA-SOW, A.; SOW, P.S.; GUÈYE, M. et al. - A characterization of pathogenic Escherichia coli in human immunodeficiency virus-related diarrhea in Senegal. J. infect. Dis., 189: 75-78, 2004.

38. GIORDANO, M.O.; MARTINEZ, L.C.; RINALDI, D. et al. - Detection of Picobirnavirus in HIV-infected patients with diarrhea in Argentina. J. Acquir. Immune Defic. Syndr Hum. Retrovirol., 18: 380-383, 1998.

39. GIORDANO, M.O.; MARTINEZ, L.C.; RINALDI, D. et al. - Diarrhea and enteric emerging viruses in HIV-infected patients. AIDS Res. hum. Retroviruses, 15: $1427-1432,1999$

40. GONCALVES, A.C.M.; FRANCO, C.; YASSAKA, M.B. et al. - Calicivirus associate diarrhea in a HIV-seropositive adult population from Southeast Brazil. In: Programs of the $\mathbf{2 0}^{\text {th }}$ International Congress of Clinical Chemistry and Laboratory Medicine, Fortaleza, Brazil, 2008. www.reference-global.com/toc/cclm/46-S1 W078.

41. GONÇALVES, A.C.M.; GABBAY, Y.B.; MASCARENHAS, J.D. et al. - Calicivirus and Giardia lamblia are associated with diarrhea in HIV-seropositive patients from Southeast Brazil. Amer. J. trop. Med. Hyg., in press.

42. GONZÁLEZ, G.G.; PUJOL, F.H.; LIPRANDI, F.; DEIBIS, L. \& LUDERT, J.E. Prevalence of enteric viruses in human immunodeficiency virus seropositive patients in Venezuela. J. med. Virol., 55: 288-292, 1998.

43. GROHMANN, G.S.; GLASS, R.I.; PEREIRA, H.G. et al. - Enteric viruses and diarrhea in HIV-infected patients. Enteric Opportunistic Infections Working Group. New Engl J. Med., 329: 14-20, 1993.

44. GUERRANT, R.L; SCHORLING, J.B ; McAULIFFE, J.F \& DE SOUZA, M.A. Diarrhea as a cause and effect of malnutrition: diarrhea prevents catch-up growth and malnutrition increases diarrhea frequency and duration. Amer. J. trop. Med. Hyg., 47: 28-35, 1992 
ROSSIT, A.R.B.; GONÇALVES, A.C.M.; FRANCO, C. \& MACHADO, R.L.D. - Etiological agents of diarrhea in patients infected by the human immunodeficiency virus-1: a review. Rev. Inst. Med. trop. S. Paulo, 51(2): 59-65, 2009.

45. HAILEMARIAM, G.; KASSU, A.; ABEBE, G. et al. - Intestinal parasitic infections in HIV/AIDS and HIV seronegative individuals in a teaching hospital, Ethiopia. Jap. J. infect. Dis., 57: 41-43, 2004.

46. HELLYER, T.J.; BROWN, I.N.; TAYLOR, M.B.; ALLEN, B.W. \& EASMON, C.S. Gastro-intestinal involvement in Mycobacterium avium-intracellulare infection of patients with HIV. J. Infect., 26: 55-66, 1993.

47. HUH, J.G.; KIM, Y.S.; LEE, J.S. et al. - Mycobacterium ulcerans infection as a cause of chronic diarrhea in an AIDS patient: a case report. Wld J. Gastroent., 14: 808-811, 2008 .

48. HUNG, C.C.; DENG, H.Y.; HSIAO, W.H. et al. - Invasive amebiasis as an emerging parasitic disease in patients with human immunodeficiency virus type 1 infection in Taiwan. Arch. intern. Med., 165: 409-415, 2005.

49. JENKIN, G.A. \& TEE, W. - Campylobacter upsaliensis-associated diarrhea in human immunodeficiency virus-infected patients. Clin. infect. Dis., 27: 816-821, 1998.

50. JOSHI, M.; CHOWDHARY, A.S.; DALAL, P.J. \& MANIAR, J.K. - Parasitic diarrhoea in patients with AIDS. Nat. med. J. India, 15: 72-74, 2002

51. KAMINSKY, R.G.; SOTO, R.J.; CAMPA, A. \& BAUM, M.K. - Intestinal parasitic infections and eosinophilia in a human immunodeficiency virus positive population in Honduras. Mem. Inst. Oswaldo Cruz, 99: 773-778, 2004.

52. KANKWATIRA, A.M.; MWAFULIRWA, G.A. \& GORDON, M.A. - Non-typhoidal salmonella bacteraemia--an under-recognized feature of AIDS in African adults. Trop. Doctor, 34: 198-200, 2004.

53. KOFFI-AKOUA, G.; FERLY-THERIZOL, M.; KOUASSI-BEUGRE, M.T. et al. Cryptosporidies et Candida dans les diarrhées infantiles à Abidjan. Bull. Soc. Path. éxot., 82: 451-457, 1989.

54. KOWNHAR, H.; SHANKAR, E.M.; RAJAN, R.; VENGATESAN, A. \& RAO, U.A. - Prevalence of Campylobacter jejuni and enteric bacterial pathogens among hospitalized HIV infected versus non-HIV infected patients with diarrhoea in Southern India. Scand. J. infect. Dis., 39: 862-866, 2007.

55. KUMAR, S.S.; ANANTHAN, S. \& LAKSHMI, P. - Intestinal parasitic infection in infected patients with diarrhoea in Chennai. Indian J. med. Microbiol., 20: 88-91, 2002 .

56. LEITE, C.A.; SUCCI, R.C.; PATRÍCIO, F.R. \& FAGUNDES-NETO, U. - Aspectos funcionais, microbiológicos e morfológicos intestinais em crianças infectadas pelo virus da imunodeficiência humana. Arq. Gastroent., 43: 310-315, 2006.

57. LEYES, M.; VARA, F.; REINA, J. et al. - Campylobacter gastroenteritis in patients with human immunodeficiency virus infection. Enferm. infecc. Microbiol. clin., 12: 332-336, 1994.

58. LINDO, J.F.; DUBON, J.M.; AGER, A.L. et al. - Intestinal parasitic infections in human immunodeficiency virus (HIV)-positive and HIV-negative individuals in San Pedro Sula, Honduras. Amer. J. trop. Med. Hyg., 58: 431-435, 1998.

59. LISTE, M.B.; NATERA, I.; SUAREZ, J.A. et al. - Enteric virus infections and diarrhea in healthy and human immunodeficiency virus infected-children. J. clin. Microbiol., 38: 2873-2877, 2000.

60. LOURENÇO, M.C.; DOS REIS, E.F.; VALLS, R.; ASENSI, M.D. \& HOFER, E. Salmonella enterica subsp houtenae serogroup O:16 in a HIV patient: case report. Rev. Inst. Med. trop. S. Paulo, 46: 169-170, 2004.

61. MADHIVANAN, P.; MOTHI, S.N.; KUMARASAMY, N. et al. - Clinical manifestations of HIV infected children. Indian J. Pediat., 70: 615-620, 2003.

62. MANATSATHIT, S.; TANSUPASAWASDIKUL, S.; WANACHIWANAWIN, D. et al. Causes of chronic diarrhea in patients with AIDS in Thailand: a prospective clinical and microbiological study. J. Gastroent., 31: 533-537, 1996.
63. MÉNDEZ, E. \& ARIAS C.F. - Astroviruses. In: KNIPE, D.M.; GRIFFIN, D.E.; LAMB, R.A. et al., ed. Fields Virology. 5. ed. Philadelphia, Lippincott, Williams \& Wilkins, 2007. p. $982-1000$.

64. MENGESHA, B. - Cryptosporidiosis among medical patients with the acquired immunodeficiency syndrome in Tikur Anbessa Teaching Hospital, Ethiopia. East Afr. med. J., 71: 376-378, 1994.

65. MÖNKEMÜLLER, K.E. \& WILCOX, C.M. - Gastrointestinal infections in children Curr. Opin. Gastroent., 17: 35-39, 2001.

66. MORGAN, U.; WEBER, R.; XIAO, L. et al. - Molecular characterization of Cryptosporidium isolates obtained from human immunodeficiency virus-infected individuals living in Switzerland, Kenya, and the United States. J. clin. Microbiol., 38: 1180-1183, 2000.

67. MOURA, H.; FERNANDES, O.; VIOLA, J.P. et al. - Enteric parasites and HIV infection occurrence in AIDS patients in Rio de Janeiro, Brazil. Mem. Inst. Oswaldo Cruz, 84: 527-533, 1989

68. MWACHARI, C.; BATCHELOR, B.I.; PAUL, J.; WAIYAKI, P.G. \& GILKS, C.F. Chronic diarrhoea among HIV-infected adult patients in Nairobi, Kenya. J. Infect., 37: 48-53, 1998.

69. NACO - National AIDS Control Organization. Available in: http://www.nacoonline.org. Accessed in 10/19/2008.

70. NIYOGI, S.K.; SAHA, M.R. \& DE, S.P. - Enteropathogens associated with acute diarrhoeal diseases. Indian J. publ. HIth, 38: 29-32, 1994.

71. OKEKE, I.N.; OJO, O.; LAMIKANRA, A. \& KAPER, J.B. - Etiology of acute diarrhea in adults in Southwestern Nigeria. J. clin. Microbiol., 41: 4525-4530, 2003.

72. PONNUVEL, K.M.; RAJKUMAR, R.; MENON, T. \& SANKARANARAYANAN, V.S. - Role of Candida in indirect pathogenesis of antibiotic associated diarrhoea in infants. Mycopathologia, 135: 145-147, 1996.

73. PRASAD, K.N.; NAG, V.L.; DHOLE, T.N. \& AYYAGARI, A. - Identification of enteric pathogens in HIV-positive patients with diarrhoea in Northern India. J. HIth Popul. Nutr., 18: 23-26, 2000

74. RAMAKRISHNAN, K.; SHENBAGARATHAI, R.; UMA, A. et al. - Prevalence of intestinal parasitic infestation in HIV/AIDS patients with diarrhea in Madurai City, South India. Jap. J. infect. Dis., 60: 209-210, 2007.

75. RIBEIRO, P.C.; PILE, E.; QUEIROZ, M.M.; NORBERG, A.N. \& TENÓRIO, J.R. Cryptosporidiosis occurrence in HIV+ patients attended in a hospital, Brazil. Rev. Saude públ. (S. Paulo), 38: 469-470, 2004.

76. RODRIGUES, J.L.; LESER, P.; SILVA, T. do M. et al. - Prevalência de criptosporidiose na síndrome diarréica do paciente HIV positivo. AMB Rev. Ass. méd. bras., 37: 79-84, 1991

77. RODRÍGUEZ-GUILLÉN, L.; VIZZI, E.; ALCALÁ, A.C. et al. - Calicivirus infection in human immunodeficiency virus seropositive children and adults. J. clin. Virol., 33: 104-109, 2005 .

78. ROSSIT, A.R.; DE ALMEIDA, M.T.; NOGUEIRA, C.A. et al. - Bacterial, yeast, parasitic and viral enteropathogens in HIV-infected children from São Paulo State, Southeastern Brazil. Diag. Microbiol. infect. Dis., 57: 59-66, 2007

79. RUIZ, J.; VARGAS, G.; VIVAR, A.; SÁNCHEZ, E. \& NAVA, E. - Mycobacterium avium intracellular duodenitis in an AIDS patient. Rev. Gastroent. Peru, 20: 76-79, 2000 .

80. SADRAEI, J.; RIZVI, M.A. \& BAVEJA, U.K. - Diarrhea, CD4 ${ }^{+}$cell counts and opportunistic protozoa in Indian HIV-infected patients. Parasit. Res., 97: 270-273, 2005 . 


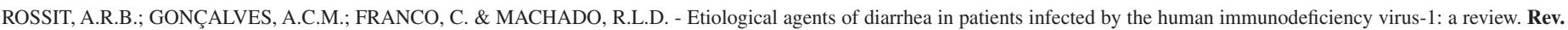
Inst. Med. trop. S. Paulo, 51(2): 59-65, 2009.

81. SAMÉ-EKOBO, A.; LOHOUÉ, J. \& MBASSI, A. - Étude clinique et biologique des diarrhées parasitaires et fongiques chez les sujets immunodéprimés dans la zone urbaine et péri-urbaine de Yaoundé. Santé, 7: 349-354, 1997.

82. SILVA, C.V.; FERREIRA, M.S.; BORGES, A.S. \& COSTA-CRUZ, J.M. - Intestinal parasitic infections in HIV/AIDS patients: experience at a teaching hospital in central Brazil. Scand. J. infect. Dis., 37: 211-215, 2005.

83. SNIJDERS, F.; KUIJPER, E.J.; DE WEVER, B. et al. - Prevalence of Campylobacterassociated diarrhea among patients infected with human immunodeficiency virus. Clin. infect. Dis., 24: 1107-1113, 1997.

84. SORVILLO, F.J.; LIEB, L.E.; KERNDT, P.R. \& ASH, L.R. - Epidemiology of cryptosporidiosis among persons with acquired immunodeficiency syndrome in Los Angeles County. Amer. J. trop. Med. Hyg., 51: 326-331, 1994.

85. STEINER, T.S.; LIMA, A.A.; NATARO, J.P. \& GUERRANT, R.L. - Enteroaggregative Escherichia coli produce intestinal inflammation and growth impairment and cause interleukin-8 release from intestinal epithelial cells. J. infect. Dis., 177: 88-96, 1998.

86. TACCONELLI, E.; TUMBARELLO, M.; VENTURA, G. et al. - Risk factors, nutritional status, and quality of life in HIV-infected patients with enteric salmonellosis. Ital. J. Gastroent. Hepatol., 30: 167-172, 1998.

87. TEIXEIRA, J.M.; CAMARA, G.N.; PIMENTEL, P.F. et al. - Human group C Rotavirus in children with diarrhea in the Federal District, Brazil. Braz. J. med. biol. Res., 31 1397-1403, 1998.

88. THERIZOL-FERLY, P.M.; TAGLIANTE-SARACINO, J.; KONE, M. et al. - Diarrhée chroniques et parasitoses chez des adultes suspectés de Sida en Côte d'Ivoire. Bull. Soc. Path. éxot., 82: 690-693, 1989.

89. THOMAS, P.D.; POLLOK, R.C. \& GAZZARD, B.G. - Enteric viral infections as a cause of diarrhoea in the acquired immunodeficiency syndrome. HIV Med., 1: 19-24, 1999.
90. UNAIDS - AIDS epidemic update 2006. Available in: http:// www.unAIDS.org. Accessed in $10 / 19 / 2008$.

91. UNAIDS - Report on the global AIDS epidemic. Available in: http:// www.unAIDS.org. Accessed in 11/04/2008.

92. VILLAMOR, E.; FATAKI, M.R.; BOSCH, R.J.; MBISE, R.L. \& FAWZI, W.W. - Human immunodeficiency virus infection, diarrheal disease and sociodemographic predictors of child growth. Acta paediat., 93: 372-379, 2004

93. WANKE, C.A.; COHAN, D.; THUMMAKUL, T. et al. - Diarrheal disease in patients infected with human immunodeficiency virus in Bangkok, Thailand. Amer. J. trop. Med. Hyg., 60: 871-874, 1999.

94. WANKE, C.A.; MAYER, H.; WEBER, R. et al. - Enteroaggregative Escherichia coli as a potential cause of diarrheal disease in adults infected with human immunodeficiency virus. J. infect. Dis., 178: 185-190, 1998.

95. WEBER, R.; LEDERGERBER, B.;ZBINDEN, R. et al. - Enteric infections and diarrhe in human immunodeficiency virus-infected persons: prospective community-based cohort study. Swiss HIV Cohort Study. Arch. intern. Med., 159: 1473-1480, 1999 .

96. WILCOX, C.M.; RABENECK, L. \& FRIEDMAN, S. - AGA technical review: malnutrition and cachexia, chronic diarrhea, and hepatobiliary disease in patient with human immunodeficiency virus infection. Gastroenterology, 111: 1724-1752, 1996

97. WUHIB, T.; SILVA, T.M.; NEWMAN, R.D. et al. - Cryptosporidial and microsporidial infections in human immunodeficiency virus-infected patients in Northeastern Brazil. J. infect. Dis., 170: 494-497, 1994

Received: 11 December 2008

Accepted: 19 February 2009 